\title{
ЭКОЛОГО-БИОЛОГИЧЕСКИЕ ФАКТОРЫ, ВЛИЯЮЩИЕ НА КАЧЕСТВО МОЛОКА У КОРОВ СИММЕНТАЛЬСКОЙ ПОРОДЫ В УСЛОВИЯХ ЯКУТИИ
}

\author{
P.N. Fedorova, O.G. Oshchepkova
}

\section{ENVIRONMENTAL AND BIOLOGICAL FACTORS INFLUENCING THE QUALITY OF MILK IN COWS OF SIMMENTAL BREED UNDER CONDITIONS OF YAKUTIA}

Федорова П.Н. - канд. биол. наук, доц. каф. фиизиологии сельскохозяйственных животных и экологии Якутской государственной сельскохозяйственной академии, г. Якутск.

E-mail: fpn56@mail.ru

Ощепкова О.Г. - асп. кафр. фризиологии сельскохозяйственных животных и экологии Якутской государственной сельскохозяйственной академии, г. Якутск.

E-mail: oxoshepkova@mail.ru

Цель исследования - изучение экологобиологических фракторов, которые влияют на качество молока у коров симментальской породы в условиях Якутии. Задачи исследования: изучение минерального состава почв; определение состава фритоценоза и исследование кормов на минеральный состав; изучение биохимического и минерального состава молока. Статистическую обработку данных осуществляли стандартными методами дисперсионного анализа по Б.А. Доспехову и А.В. Ваулину, уровень значимости различий вариационных рядов оценивали параметрическим $t$-критерием Стьюдента с использованием редактора Microsoft Excel. Onределено среднее содержание микроэлементов ( $\mathrm{Zn}, \mathrm{Cu}, \mathrm{Co}, \mathrm{I}, \mathrm{Mn}, \mathrm{Se}$ ) в верхнем слое почв в исследуемых районах республики. Установлено, что данные участки ежегодно подтапливаются весенними паводками, вымывая большую часть солей и минералов, вследствие чего почва становится щелочной, влияющей на рост и развитие растений. Элементы растений, поедаемье животными, по трофрическим цепям переходят в организм, а, следовательно, в продукт (мясо, молоко). Для установления более полной картины влияния кормов на продукцию изучены питательность и
Fedorova P.N. - Cand. Biol. Sci., Assoc. Prof., Chair of Physiology of Farm Animals and Ecology, Yakut State Agricultural Academy, Yakutsk.

E-mail: fpn56@mail.ru

Oshchepkova O.G. - Post-Graduate Student, Chair of Physiology of Farm Animals and Ecology, Yakut State Agricultural Academy, Yakutsk.

E-mail: oxoshepkova@mail.ru

содержание микроэлементов в кормах. Изучен химический и фризико-химический состав молока коров симментальской породы исследуемых районов в зимний и летний периоды. В республике наиболее иенное молоко по фризикохимическим и минеральному составу производится в летнее время года. Исследование показало, что биохимический состав зависит от состава почвы, а почва зависит от гранулометрического состава, климата, кислотности. По этой причине рационы кормления крупного рогатого скота не сбалансированы по протеину, макро- и микроэлементам, витаминам, что приводит к значительному снижению молочной продуктивности скота и ухудшению качества производимой продукции. Содержание минеральных веществ в молоке коров находится на оптимальном уровне. Характерным для якутского региона является недостаток йода. Это необходимо учитывать при балансировании рационов для скота, особенно при кормлении сухостойных коров.

Ключевые слова: симментальская порода, Республика Саха (Якутия), микроэлементы в почвах, фитоценоз, питательность корма, минеральный состав молока. 
The purpose of the research was to study some factors affecting the quality of milk of Simmental cows in Yakutia. The research problems were studying mineral structure of soils; the definition of the structure of phytocenosis and the research of forages on mineral structure; studying of biochemical and mineral composition of milk. Statistical data processing was carried out by standard methods of dispersive analysis according to B.A. Dospekhov and A.V. Vaulin, the significance value of distinctions of variation ranks was estimated by parametrical tcriterion of Student together with Microsoft Excel editor. Average content of microelements ( $\mathrm{Zn}, \mathrm{Cu}$, $\mathrm{Co}, \mathrm{I}, \mathrm{Mn}, \mathrm{Se}$ ) in the top layer of soils in studied areas of the republic was determined. It was established that these sites were annually waterlogged by spring floods, washing away the most part of salts and minerals owing to it the soil became alkaline, influencing the growth and development of plants. The elements of plants eaten by animals on trophic chains pass into an organism, and, therefore, into a product (meat, milk). For the establishment of fuller picture of the influence of forages on production nutrition quality and the maintenance of microelements in sterns were studied. Chemical and physical and chemical composition of milk of cows of Simmental breed of investigated areas during winter and summer period was studied. In the republic the most valuable milk on physical and chemical and mineral structure is made summer pasture period. The researches showed that biochemical structure depended on the structure of the soil, and the soil depended on particle size distribution, climate and acidity. For this reason the ration of cattle feeding is not balanced in protein, macro- and microelements, vitamins leading to considerable decrease in dairy efficiency of cattle and deterioration of made production. The content of mineral substances in milk of cows is at an optimum level. For Yakut Region the lack of iodine is characteristic. It needs to be considered when balancing the diets for cattle, especially when feeding dry cows.

Keywords: Simmental breed, the Republic of Sakha (Yakutia), trace elements in soils, phytocenosis, nutritional value of feed, mineral milk composition.

Введение. Общеизвестно, что качество продуктов питания человека по цепочке «почва растение - животное - продукция» зависит от экологической среды, климата, а также физиологического состояния, породы, возраста молочного скота от условий его содержания и кормления. С продуктами питания в организм человека поступает значительная часть химических и биологических веществ, в том числе и тяжелые металлы. Они попадают, накапливаются по ходу биологической цепи: почва (вода) - растение - животное - продукция - человек $[4,5,8]$. В связи с этим изучение эколого-биологических фракторов, влияющих на качество молока у коров симментальской породы, представляет определенный научный и практический интерес. Отметим, что в условиях рыночной экономики эта порода активно конкурирует с другими породами, сохраняя основное направление продуктивности молочно-мясное [3].

Цель исследования: изучение экологобиологических фракторов, которые влияют на качество молока у коров симментальской породы в условиях Якутии.

Задачи исследования: изучение минерального состава почв; определение состава фитоценоза и исследование кормов на минеральный состав; изучение биохимического и минерального состава молока.

Методы исследования. Образцы почв (слой 0-20 см) исследуемых районов отбирали в период вегетации растений (май - сентябрь) по общепринятым методикам, согласно ГОСТ 17.4.4.02-84. Агрохимические показатели исследованы в республиканской агрохимстанции в г. Якутске. Отбор проб сена и зеленой травы проводили по ГОСТ 27262-87. Отбор проб грубых кормов (сено) проводили по ГОСТ 27262-87 [9]. Доступные растениям и кормам микроэлементы определяли в спектрофотометре «Спектростар» лаборатории Якутской ГСХА. Физико-химический состав, содержание жира, белка, сухого обезжиренного молочного остатка (СОМО) определяли на экспресс-анализаторе молока «Клевер-2». Минералы молока определяли атомным спектрофотометром «Люмекс- МС9100».

Результаты исследования. Сельскохозяйственное производство Якутии размещено в зоне вечной мерзлоты, резко континентального климата и неустойчивого увлажнения. Из всех факторов внешней среды наиболее важным и стабильным экологическим фактором является низкая температура воздуха [6]. 
Минеральный состав почвы. Содержание и распределение в почве микроэлементов зависят от направления и степени развития почвообразовательного процесса и особенностей поведения микроэлементов в ландшафте [1]. Низкие температуры отрицательно влияют на интенсивность почвообразовательных процессов и на продуктивность растений. Верхний почвенный слой к осени оттаивает от 20-30 см в северной части до 150-200 см в центральной и южной частях территории республики.

В Хангаласском районе исследуемая пойменная терраса заливается каждый год в период весеннего половодья, представлена аллювиально-дерновым типичным типом мерзлотных почв. В Мегино-Кангаласском и в Сунтарском районах исследуемая аласная экосистема представлена аласно-луговым черноземным типом мерзлотных почв.

Нами было определено среднее содержание микроэлементов ( $\mathrm{Zn}, \mathrm{Cu}, \mathrm{Co}, \mathrm{I}, \mathrm{Mn}, \mathrm{Se})$ в верхнем слое почв (0-20 см) (табл. 1). Установлено, что для почвенного покрова районов Тюнгюлю и Аллага не свойственны превышающее предельнодопустимые концентрации или другие критические показатели фоновых содержаний элементов $\mathrm{Co}, \mathrm{Mn}, \mathrm{Zn}, \mathrm{Cu}$. В почвенно-климатической зоне района Улах-Ан содержание микроэлементов Со, $\mathrm{Mn}, \mathrm{Zn}, \mathrm{Cu}$ превышает показатели района Тюнгюлю в 2 раза, а с Сунтарским районом - в 1,5 раза. Это может быть обусловлено тем, что участок находится в 300 м от территории прохождения федеральной автомобильной трассы, которая функционирует не один десяток лет.

Содержание микроэлементов в почвах, мг/кг

Таблица 1

\begin{tabular}{|c|c|c|c|c|c|c|c|c|}
\hline Тип почвы & Глубина, см & Se & Co & I & $\mathrm{Mn}$ & $\mathrm{Zn}$ & $\mathrm{Cu}$ & Кислотность \\
\hline \multicolumn{9}{|c|}{ с. Улах-Ан, Хангаласский район } \\
\hline \multirow{3}{*}{$\begin{array}{l}\text { Пойменно- } \\
\text { аллювиально- } \\
\text { дерновая } \\
\text { типичная почва }\end{array}$} & $0-5$ & 2,68 & 4,86 & 1,4 & 69,63 & 22,48 & 3,97 & \multirow{3}{*}{4} \\
\hline & $5-10$ & 2,45 & 2,76 & 1,8 & 58,81 & 20,77 & 2,76 & \\
\hline & 10-20 & 3 & 3 & 2,5 & 60,17 & 17,86 & 1,99 & \\
\hline \multicolumn{9}{|c|}{ с.Тюнгюлю, Мегино-Кангаласский район } \\
\hline \multirow{3}{*}{$\begin{array}{l}\text { Аласные } \\
\text { лугово- } \\
\text { черноземные } \\
\text { почвы }\end{array}$} & $0-5$ & 3,33 & 2,56 & 2,5 & 35,53 & 6,77 & 1,99 & \multirow{3}{*}{7,2} \\
\hline & $5-10$ & 4,1 & 1,66 & 1,8 & 38,91 & 5,98 & 1,58 & \\
\hline & 10-20 & 3,59 & 2 & 2,3 & 30,67 & 4,68 & 1,50 & \\
\hline \multicolumn{9}{|c|}{ с. Аллага, Сунтарский район } \\
\hline \multirow{3}{*}{$\begin{array}{l}\text { Аласные } \\
\text { лугово- } \\
\text { черноземные } \\
\text { почвы }\end{array}$} & $0-5$ & 3.52 & 2,54 & 2,3 & 44,53 & 10,77 & 2,36 & \multirow{3}{*}{7} \\
\hline & $5-10$ & 3,58 & 2,86 & 2,73 & 38,91 & 9,98 & 1,98 & \\
\hline & 10-20 & 3,1 & 3,1 & 2,47 & 45,67 & 5,68 & 1,80 & \\
\hline \multicolumn{2}{|c|}{$\begin{array}{l}\text { Предельно допустимая } \\
\text { концентрация (ПДК夫) }\end{array}$} & $5-10$ & $0-5$ & $5-40$ & 0-1500 & $0-23$ & $0-3$ & $4,4-7$ \\
\hline
\end{tabular}

*ПДК - нормативы предельно-допустимых концентраций России (валовые). Значения ПДК даны в соответствии с Перечнем ПДК и ОДК химических веществ в почве.

Концентрация I и Se в почвах исследуемых районов десрицитная. Причина может быть в низком валовом содержании элемента, фризикохимических свойствах почвы и свойствах самих галогенов. Кислотность почв на территории УлахАн высокая. В кислой среде увеличивается подвижность меди, марганца, цинка. Таким образом, в почвенном покрове определенной территории наблюдается отчетливая диффреренциация в содержании и распределении микроэлементов.

В исследованных почвах села Тюнгюлю и Аллага реакция среды щелочная. В Улах-Ане кислая среда, в кислой среде концентрация тяжелых металлов увеличивается и они становятся более подвижными, а содержание селена уменьшается. В целом почва в районе Улах-Ана подвергается значительному техногенному прессингу, попадая в зону влияния выхлопов автомобилей.

Ботанический состав фритоценозов. Фитоценоз Хангаласского района, села Улах-Ан характеризуется довольно незначительным разнообразием - 25 видов растений из 10 семейств. Следует отметить, что в Мегино-Кангаласском районе, в селе Тюнгюлю представлено самое большое раз- 
нообразие - 38 видов растений из 10 семейств. В Сунтарском районе села Аллага распространены 35 видов растений из 10 семейств. Во всех трех районах широко распространены растения семейства Роасеае. Они являются ценным высокоурожайным кормом, пригодным для сенокосов и пастбищ, по питательности занимают одно из первых мест среди многолетних злаковых трав.

Также были отмечены в трех районах хозяйственно-вредные растения - представитель семейства Rubiaceae Juss., вид растения Galium verum L. вызывающее порчу молока [2]. В описываемом фитоценозе зарегистрирована сорная растительность, виды с прикорневой листовой розеткой, вытесняющие луговые травы семейства Plantagenaceae и Asteraceae.

В Улах-Ане встречается горец птичий, относящийся к ценным пастбищным растениям, характеризующийся высоким содержанием протеина и отличной поедаемостью животными.

Растения семейства Fabaceae имеют высокую питательную ценность для животных. В исследуемых районах встречаются повсеместно. Данные растения очень хорошо поедаются скотом. В растениях клевера содержится до 17 \% протеина, а также значительное количество кальция, калия и каротина [7].

Самое большое видовое разнообразие фиитоценоза в пастбищах выражено в МегиноКангаласском районе (село Тюнгюлю) и в Сунтарском районе (село Аллага), так как эти села отдаленные, малозаселенные, следовательно, нет перевыпаса скота.
В Хангаласском районе села Улах-Ан очень скудный видовой состав растений. Участок подтапливает весенним паводком каждый год, из-за чего вымывается большая часть солей и минералов и почва становится щелочной, все это влияет на рост и развитие растений. Также пастбище находится в 300 м от автотрассы, откуда попадают вредные вещества. В этой связи, на наш взгляд, для улучшения видового состава необходимо посеять бобовые виды растений, регулировать выпас скота.

Питательность и минеральный состав корма в районах исследования. Уровень кормления, структура рационов и содержание животных влияют на качество молочной продуктивности. Наибольшие значительные изменения в качестве молока зависят от уровня белкового и минерального питания, от вида основных кормов [7].

Для установления более полной картины влияния кормов на продукцию нами были изучены питательность и содержание микроэлементов в кормах (табл. 2-4). Полученные данные свидетельствуют о том, что содержание каротина в кормах (сено) и зеленой массе (траве) из аласных угодий сел Тюнгюлю и Аллага относительно стабильно во времени и колеблется в незначительных пределах в течение 2017-2018 гт. исследования (см. табл. 2). Следует учесть, что показатель сена (разнотравное) и зеленой массы пойменного угодья села Улах-Ан в два раза ниже показателей сел Тюнгюлю и Аллага. Питательность сена и зеленой массы по ОКЕ соответствует среднестатистическим нормативам.

Таблица 2

Питательность и состав сена и зеленой массы разных сенокосных угодий, $n=25$, мг/кг

\begin{tabular}{|l|c|c|c|}
\hline \multirow{2}{*}{ Показатель } & \multicolumn{2}{|c|}{ Аласные } & Пойменные \\
\cline { 2 - 4 } & с. Тюнгюлю & с. Аллага & с. Улах-Ан \\
\hline \multicolumn{4}{|c|}{ Сено (разнотравное) } \\
\hline Каротин & $17,3 \pm 3,28$ & $17,0 \pm 0,67$ & $8,5 \pm 1,05$ \\
\hline Питательность 1 кг, КЕ & $0,70 \pm 0,05$ & $0,65 \pm 0,08$ & $0,53 \pm 0,07$ \\
\hline \multicolumn{4}{|c|}{ Зеленая трава пастбищная } \\
\hline Каротин & $20,5 \pm 2,14$ & $20,1 \pm 1,71$ & $11,6 \pm 1,05$ \\
\hline Питательность 1 кг, КЕ & $0,95 \pm 1,8$ & $0,90 \pm 1,2$ & $0,90 \pm 1,5$ \\
\hline
\end{tabular}

Примечание: все полученные данные достоверны, $\mathrm{P} \leq 0,001$.

Исследования микроэлементного состава сена и пастбищной травы показывают, что в сене пойменных угодий Улах-Ан содержится повышенное концентрация таких микроэлементов, как медь, кобальт, марганец и цинк. Отме- чается также пониженное содержание селена, в селе Тюнгюлю и Аллага - в пределах нормы. Содержание йода десицитное во всех трех районах. 
Микроэлементный состав сена исследуемых пастбищ, $n=15, \mathrm{mr} / к г$

\begin{tabular}{|l|c|c|c|}
\hline Показатель & $\begin{array}{c}\text { с. Тюнгюлю } \\
\text { (аласные) } \\
\mathrm{M}_{1} \pm \mathrm{m}_{1}\end{array}$ & $\begin{array}{c}\text { с. Улах-Ан } \\
\text { (пойменные луга) } \\
\mathrm{M}_{2} \pm \mathrm{m}_{2}\end{array}$ & $\begin{array}{c}\text { с. Аллага } \\
\text { (аласные) } \\
\mathrm{M}_{3} \pm \mathrm{m}_{3}\end{array}$ \\
\hline $\mathrm{Cu}$ & $6,7 \pm 1,5$ & $9,5 \pm 2,2$ & $7,4 \pm 1,5$ \\
\hline $\mathrm{Co}$ & $25,7 \pm 0,27$ & $30,1 \pm 2,35$ & $80 \pm 1,9$ \\
\hline $\mathrm{Mn}$ & $59 \pm 0,54$ & $78,56 \pm 0,80$ & $65 \pm 0,71$ \\
\hline $\mathrm{Zn}$ & $3,8 \pm 0,10$ & $67,7 \pm 0,50$ & $4,8 \pm 0,15$ \\
\hline $\mathrm{I}$ & $0,9 \pm 0,11$ & $0,5 \pm 0,47$ & $0,9 \pm 0,21$ \\
\hline $\mathrm{Se}$ & $0,009 \pm 2,5$ & $0,003 \pm 1,9$ & $0,008 \pm 1,8$ \\
\hline
\end{tabular}

Примечание: все полученные данные достоверны, $\mathrm{P} \leq 0,05$.

Таблица 4

Микроэлементный состав зеленой травы исследуемых пастбищ, $\mathrm{n}=15, \mathrm{mr} / к г$

\begin{tabular}{|l|c|c|c|}
\hline Показатель & $\begin{array}{c}\text { с. Тюнгюлю } \\
\text { (аласные) } \\
\mathrm{M}_{1} \pm \mathrm{m}_{1}\end{array}$ & $\begin{array}{c}\text { с. Улах-Ан } \\
\text { (пойменные луга) } \\
\mathrm{M}_{2} \pm \mathrm{m}_{2}\end{array}$ & $\begin{array}{c}\text { с. Аллага } \\
\text { (аласные) } \\
\mathrm{M}_{3} \pm \mathrm{m}_{3}\end{array}$ \\
\hline $\mathrm{Cu}$ & $20,1 \pm 3,5$ & $24,7 \pm 2,2$ & $23 \pm 1,5$ \\
\hline $\mathrm{Co}$ & $76,67 \pm 0,95$ & $85,67 \pm 2,35$ & $80 \pm 1,9$ \\
\hline $\mathrm{Mn}$ & $59 \pm 0,54$ & $65 \pm 0,71$ & $48,5 \pm 0,71$ \\
\hline $\mathrm{Zn}$ & $160,52 \pm 0,37$ & $237,4 \pm 0,48$ & $180,53 \pm 0,50$ \\
\hline $\mathrm{I}$ & $0,20 \pm 0,8$ & $0,15 \pm 0,17$ & $0,18 \pm 0,11$ \\
\hline $\mathrm{Se}$ & $0,024 \pm 0,16$ & $0,018 \pm 0,1$ & $0,020 \pm 0,2$ \\
\hline
\end{tabular}

Примечание: все полученные данные достоверны, $\mathrm{P} \leq 0,05$.

Из данных исследования видно, что корма естественных пастбищных угодий по своему составу полноценные. Пастбищный период в Якутии длится всего 120-140 дней в году, тогда как в средней полосе России - 180-190 дней в году. Данные свидетельствуют о том, что питательность и микроэлементный состав полноценного корма КРС наблюдается в летний пастбищный период. Отсюда, чтобы обеспечить животных полноценным питательным рационом в условиях Якутии, а именно в зимний период, необходимо применение концентрированных кормов и минеральных добавок.

Физико-химические показатели молока. Состав молока непостоянен, все питательноминеральные вещества поступают в зависимости от сезона и ряда других факторов, таких как содержание, кормление, порода, возраст, период лактации, техника доения, состояние животного и ряда других физиологических особенностей [10].

Нами был изучен химический и физикохимический состав молока коров симментальской породы исследуемых районов в зимний и летний периоды (табл. 5). В зимний период наблюдалось снижение содержания химического и физико-химического состава молока у всех лактирующих коров. В этот период повсеместно уменьшается запас кормов, резерв питательных веществ в организме коров, и это отражается на составе молока. По содержанию в молоке жира, общего белка, СОМО коровы с. Тюнгюлю МегиноКангаласского улуса превосходят коров двух других исследуемых районов. В летнее время жирность молока во всех исследуемых районах возрастала от 4 до $5 \%$. 
Химический и физико-химический состав молока симментальской породы коров по сезонам года исследуемых районов

\begin{tabular}{|c|c|c|c|c|}
\hline Показатель & $\begin{array}{c}\text { Кол-во } \\
\text { голов }\end{array}$ & $\begin{array}{c}\text { 3има } \\
\left(\mathrm{M}_{1} \pm \mathrm{m}_{1}\right)\end{array}$ & $\begin{array}{c}\text { Лето } \\
\left(\mathrm{M}_{2} \pm \mathrm{m}_{2}\right)\end{array}$ & Норма \\
\hline \multicolumn{5}{|c|}{ с. Улах-Ан } \\
\hline Массовая доля белка, \% & \multirow{5}{*}{10} & $3,2 \pm 0,1$ & $3,40 \pm 0,02$ & 3,5 \\
\hline Массовая доля жира, \% & & $3,87 \pm 0,02$ & $4,10 \pm 0,01$ & 3,8 \\
\hline Кислотность, ${ }^{\circ} \mathrm{T}$ & & $16 \pm 0,05$ & $17,5 \pm 0,09$ & 16 \\
\hline COMO, \% & & $8,60 \pm 0,01$ & $8,75 \pm 0,01$ & 8,7 \\
\hline Сухое вещество, \% & & $12,30 \pm 0,03$ & $12,31 \pm 0,06$ & 12,7 \\
\hline \multicolumn{5}{|c|}{ с. Тюнгюлю } \\
\hline Массовая доля белка, \% & \multirow{5}{*}{10} & $3,49 \pm 0,4$ & $3,57 \pm 0,05$ & 3,5 \\
\hline Массовая доля жира, \% & & $3,94 \pm 0,05$ & $5,0 \pm 0,10$ & 3,8 \\
\hline Кислотность, оТ & & $17 \pm 0,01$ & $17,5 \pm 0,05$ & 16 \\
\hline $\mathrm{COMO}, \%$ & & $8,97 \pm 0,08$ & $9,18 \pm 0,12$ & 8,7 \\
\hline Сухое вещество, \% & & $13,20 \pm 0,08$ & $13,87 \pm 0,01$ & 12,7 \\
\hline \multicolumn{5}{|c|}{ с. Аллага } \\
\hline Массовая доля белка, \% & \multirow{5}{*}{10} & $3,66 \pm 0,01$ & $3,64 \pm 0,02$ & 3,5 \\
\hline Массовая доля жира, \% & & $3,89 \pm 0,03$ & $4,23 \pm 0,09$ & 3,8 \\
\hline Кислотность, оТ & & $17 \pm 0,05$ & $17,01 \pm 0,04$ & 16 \\
\hline COMO, \% & & $8,70 \pm 0,01$ & $8,75 \pm 0,01$ & 8,7 \\
\hline Сухое вещество,\% & & $12,99 \pm 0,09$ & $13,01 \pm 0,13$ & 12,7 \\
\hline
\end{tabular}

Примечание: все полученные данные достоверны, $\mathrm{P} \leq 0,05$.

Общая тенденция изменчивости содержания жира и белка в молоке по сезонам года во всех трех районах практически схожа. Кислотность молока исследуемых коров была в норме и не превышала уровня 16-18 0Т. Таким образом, установлено, что молоко летом по своему составу является более ценным, чем в зимнее время года, что соответствует с данными других авторов. В этот период происходит снижение суточных удоев у коров. Сравнивая фризикохимический состав молока исследуемых коров с нормой, приведенной в справочной литературе, можно сказать, что показатели имеют более высокие значения.

В таблице 6 приведен минеральный состав молока коров симментальской породы в стойловый период. Согласно полученным данным, содержание элементов цинка, меди, кобальта и марганца завышено в селе Улах-Ан, а в селе
Тюнгюлю и Аллага оно стабильно. Острая нехватка элемента йода наблюдается во всех трех районах. Содержание селена в Улах-Ан достоверно низкое, в последующих двух районах его концентрация в допустимых пределах.

Накопление макро- и микроэлементов в разных биогеохимических ландшафтах в кормах и растениях оказалось разным. Следовательно, наблюдается разное содержание минеральных веществ в молоке по зонам республики.

Таким образом, исследование показало, что содержание минеральных веществ в молоке коров находится на приемлемом уровне. Недостаток йода является характерным показателем для исследуемого региона. Такие особенности необходимо учитывать при балансировании рационов для скота, в частности при кормлении сухостойных коров. 


\section{Микроэлементный состав молока симментальской породы коров в исследуемых группах, мкг/г}

\begin{tabular}{|l|c|c|c|c|}
\hline \multirow{2}{*}{ Микроэлемент } & Ср. зн. по ли- & \multicolumn{3}{|c|}{ Район исследований } \\
\cline { 3 - 5 } & данным, мкг/кг & $\begin{array}{c}\text { с. Улах-Ан } \\
\left(\mathrm{M}_{1} \pm \mathrm{m}_{1}\right)\end{array}$ & $\begin{array}{c}\text { с. Тюнгюлю } \\
\left(\mathrm{M}_{2} \pm \mathrm{m}_{2}\right)\end{array}$ & $\begin{array}{c}\text { с. Аллага } \\
\left(\mathrm{M}_{3} \pm \mathrm{m}_{3}\right)\end{array}$ \\
\hline $\mathrm{Zn}$ & 0,50 & $0,41 \pm 0,007$ & $0,34 \pm 0,004$ & $0,36 \pm 0,006$ \\
\hline $\mathrm{Co}$ & $1-39$ & $0,71 \pm 0,003$ & $0,48 \pm 0,003$ & $0,61 \pm 0,02$ \\
\hline $\mathrm{I}$ & $0-700$ & $0,05 \pm 0,0004$ & $0,09 \pm 0,0006$ & $0,07 \pm 0,0001$ \\
\hline $\mathrm{Cu}$ & 1 & $0,0464 \pm 0,00004$ & $0,0062 \pm 0,00015$ & $0,0164 \pm 0,00002$ \\
\hline $\mathrm{Mn}$ & $7-600$ & $0,05955 \pm 0,0007$ & $0,05255 \pm 0,0004$ & $0,04208 \pm 0,0004$ \\
\hline $\mathrm{Se}$ & 0,023 & $0,01992 \pm 0,0008$ & $0,01012 \pm 0,002$ & $0,01172 \pm 0,0003$ \\
\hline
\end{tabular}

Примечание: все полученные данные достоверны, $\mathrm{P} \leq 0,05$.

\section{Выводы}

1. Почвы естественных пастбищ содержат элементы преимущественно природного происхождения, достаточно равномерно распределенные по различным почвенно-климатическим зонам региона. Элементный состав почв района исследования можно представить в виде ряда (в порядке снижения концентраций): $\mathrm{Mn}>\mathrm{Zn}>$ $\mathrm{Cu}>\mathrm{Co}>\mathrm{Se}>\mathrm{I}$. Почвы села Улах-Ан представлены пойменным аллювиально-дерновым типичным типом почв, обладающим кислой реакцией среды, которая оказывает влияние на подвижность и концентрацию микроэлементов марганца, цинка, меди и кобальта. Села Тюнгюлю и Аллага представлены аласно-лугово-черноземными почвами со щелочной реакцией среды. Концентрация элементов в пределах нормы. Но содержание йода во всех исследуемых участках критично мало.

2. Уровень загрязнения и затопления пастбищ привел к снижению видового разнообразия и доли ценных кормовых растений в фитоценозах и увеличению в них сорных растений. Состояние автотрофного звена пастбища села Улах-Ан свидетельствует об ухудшении экологических условий в зоне: почва - растение корма. Химический состав и питательность кормов, используемых в рационах коров, зависят от урожайности растений и метеорологических условий. Содержание минеральных веществ и каротина не отвечают требованиям ГОСТа. Содержание меди, кобальта, цинка не обеспечивают потребности коров, так как имеет низкий показатель. Неполноценное кормление вызы- вает ослабление организма коров и всех функциональных особенностей.

3. В республике наиболее ценное молоко по физико-химическому и минеральному составу производится в летнее время года. Исследования показали, что биохимический состав зависит от состава почвы, а почва зависит от гранулометрического состава, климата, кислотности. По этой причине рационы кормления крупного рогатого скота не сбалансированы по протеину, макро- и микроэлементам, витаминам, что приводит к значительному снижению молочной продуктивности скота и ухудшению качества производимой продукции. Таким образом, связь между компонентами почва - растение - животное - продукция неразрывная.

\section{Литература}

1. Алексеев Ю.В. Тяжелые металлы в почвах и растениях. - Л.: Агромпромиздат, 1987. C. 142.

2. Ананьева Э.В., Прокопчук В.Ф. Влияние длительного применения удобрений на потребление микроэлементов сельскохозяйственными культурами // Проблемы и перспективы семеноводства полевых культур в Дальневосточном и Сибирском регионах: сб. науч. тр. - Благовещенск, 2007. C. 152-158.

3. Анисимова Е.И., Гостева Е.Р., Улимбашев М.Б. Зависимость молочной продуктивности коров симментальской породы от различных факторов // Вестник АПК Ставрополья. 2016. - № 3 (23). - C. 84-87. 
4. Аргунов М.Н. Ветеринарная токсикология с основами экологии. - СПб.: Лань, 2007. C. 8-35.

5. Баранников В.Д., Кириллов Н.К. Экологическая безопасность сельскохозяйственной продукции. - М.: КолосС, 2005. - 352 с.

6. Гаврилова М.К. Климат Центральной Якутии. - Якутск: Якут. кн. изд-во, 1973. - 119 с.

7. Голов В.И., Самохвалова О.С., Ананьева Э.В., Тимофеев А.Н. Условия накопления микроэлементов и тяжелых металлов основными кормовыми культурами на почвах Амурской области // Вестн. КрасГАУ. - 2007. - № 2. C. 59-62.

8. Кривошеин Д.А., Муравей Я.А., Роева Н.Н. Экология и безопасность жизнедеятельности. - М.: ЮНИТИ-ДАНА, 2000. - 447 с.

9. Молянова Г.В. Влияние холодного периода года Среднего Поволожья на динамику общего белка и его фракций в крови свиней при коррекции тимозином-а1 // Ученые записки. - Казань, 2011. - Т. 207. - С. 356360.

10. Сьчева О., Степанцова Л. Внедрение нового ГОСТа при сдаче-приёмке молока в Ставрополье // Молочное и мясное скотоводство. - 2004. - № 7. - С. 21-22.

\section{Literatura}

1. Alekseev YU.V. Tyazhelye metally v pochvah $\mathrm{i}$ rasteniyah. - L.: Agrompromizdat, 1987. S. 142.

2. Anan'eva E.V., Prokopchuk V.F. Vliyanie dlitel'nogo primeneniya udobrenij na potreblenie mikroelementov sel'skohozyajstvennymi kul'turami // Problemy i perspektivy semenovodstva polevyh kul'tur v Dal'nevostochnom i Sibirskom regionah: sb. nauch. tr. - Blagoveshchensk, 2007. - S. 152158.

3. Anisimova E.I., Gosteva E.R., Ulimbashev M.B. Zavisimost' molochnoj produktivnosti korov simmental'skoj porody ot razlichnyh faktorov // Vestnik APK Stavropol'ya. - 2016. № 3 (23). - S. 84-87.

4. Argunov M.N. Veterinarnaya toksikologiya $\mathrm{s}$ osnovami ekologii. - SPb.: Lan', 2007. S. 8-35.

5. Barannikov V.D., Kirillov N.K. Ekologicheskaya bezopasnost' sel'skohozyajstvennoj produkcii. - M.: KolosS, 2005. - 352 c.

6. Gavrilova M.K. Klimat Central'noj YAkutii. YAkutsk: YAkut. kn. izd-vo, 1973. - 119 s.

7. Golov V.I., Samohvalova O.S., Anan'eva E.V., Timofeev A.N. Usloviya nakopleniya mikroelementov i tyazhelyh metallov osnovnymi kormovymi kul'turami na pochvah Amurskoj oblasti // Vestn. KrasGAU. - 2007. № 2. - S. 59-62.

8. Krivoshein D.A., Muravej YA.A., Roeva N.N. Ekologiya i bezopasnost' zhiznedeyatel'nosti. M.: YUNITI-DANA, 2000. - $447 \mathrm{~s}$.

9. Molyanova G.V. Vliyanie holodnogo perioda goda Srednego Povolozh'ya na dinamiku obshchego belka i ego frakcij v krovi svinej pri korrekcii timozinom-a1 // Uchenye zapiski. Kazan', 2011. - T. 207. - S. 356-360.

10. Sycheva O., Stepancova L. Vnedrenie novogo GOSTa pri sdache-priyomke moloka $\mathrm{V}$ Stavropol'e // Molochnoe i myasnoe skotovodstvo. - 2004. - № 7. - S. 21-22. 